www.jmscr.igmpublication.org Impact Factor 5.244

Index Copernicus Value: 5.88 ISSN (e)-2347-176x ISSN (p) 2455-0450 crossref DOI:_http://dx.doi.org/10.18535/jmscr/v4i6.39

\title{
Comparison of Bacterial Count in Unsterilised Plastic Cups Vs Autoclaved Stainless Steel Cups
}

\author{
Authors \\ Rathna Subhashini.M.H, Dr Abirami.G \\ Corresponding author \\ Rathna Subhashini.M.H \\ BDS III year \\ 162, Saveetha Dental College, Vellapanchavadi, Poonamelle high road, Chennai-600077 India \\ Email: rathnasweety72@gmail.com
}

\begin{abstract}
AIM: The aim of this study is to compare the presence of bacterial count in unsterilized plastic cups Vs autoclaved stainless steel cups.

OBJECTIVE: This study helps in finding out a best alternative for unsterilized plastic cups used in dental practices.

BACKGROUND: Unsterilized plastic cups are now very commonly used in dental practices. The major drawback for using those cups is that they cannot be sterilized or disinfected. These plastic cups are stored in an environment where they get contaminated by aerosols. Furthermore there is no effective way to dispose or recycle them and they end up in landfills or burnt, which in turn releases harmful carcinogens into the soil, water and air. Therefore, it becomes mandatory and the need of the hour to find a sustainable alternative for plastic cups used in dental practice.
\end{abstract}

KEY WORDS: Dental practice, plastic cups, sterilization, autoclave, aerosol.

\section{INTRODUCTION}

The main purpose of this study is to minimize using plastic cups in general dental practice which can be replaced by stainless cups. Recent studies, one million plastic cups are disposed into landfills in Toronto every day, which again cause harm for the earth ${ }^{[1] .}$ Using autoclaved stainless steel cups helps in reducing the number of plastic cups sent to landfills. Moreover, as plastic cups are not effectively sterilized, and there are pathogens which may again cause harm to patients in dental treatment. The purpose of this investigation was to qualitatively and quantitatively assess bacterial and fungal contamination of plastic cups which is routinely used in dental office. An assay system was devised for comparison of the efficacy of various methods of sterilizing stainless steel instruments in order to establish a suitable method for decontamination of stainless instruments used in dental practice. 


\section{JMSCR Vol||04||Issue||06||Page 10915-10918||June}

TEST MATERIAL

20 plastic cups

20 sterilized stainless cups

\section{METHODOLOGY}

Swab from both plastic cups and sterilized stainless steel cups were taken individually using cotton swab and were loaded in culture plates with culture media. Each plates were incubated at 37 degree Celsius overnight and the zones bacterial colonization were seen. The bacterial colonies were counted in each plates and mean value was calculated. All the tests are done in triplicate to minimize test errors.
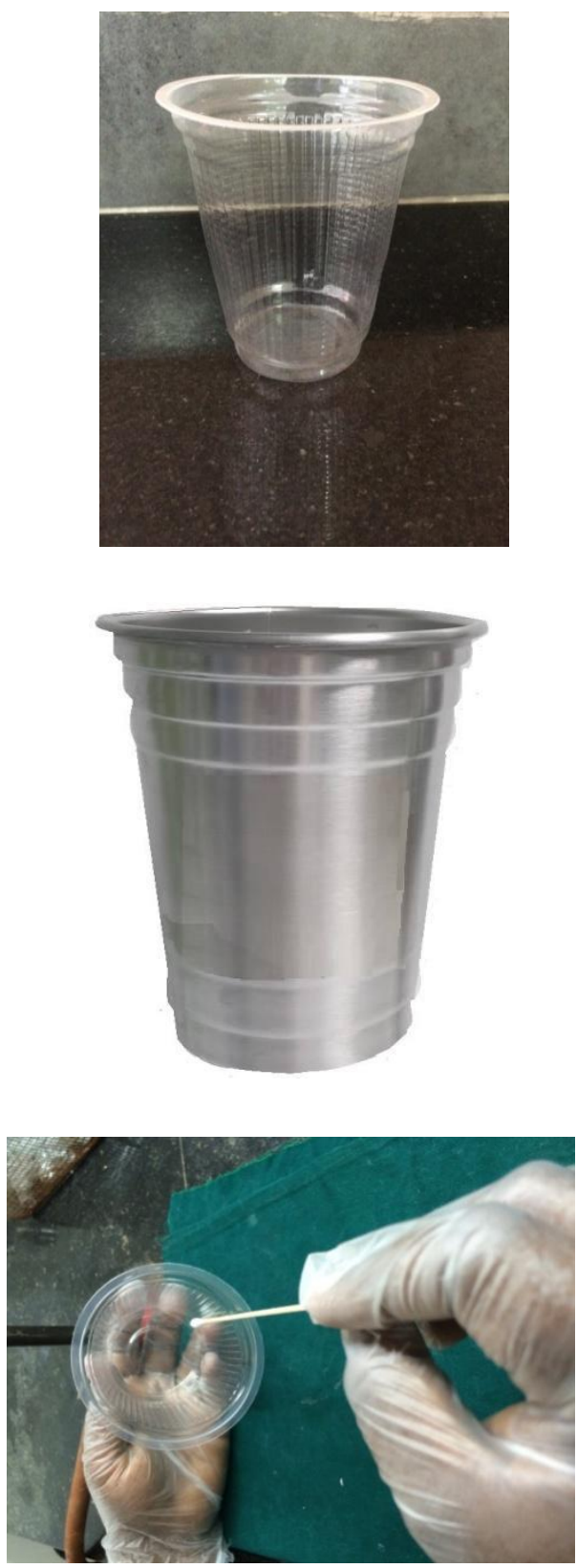
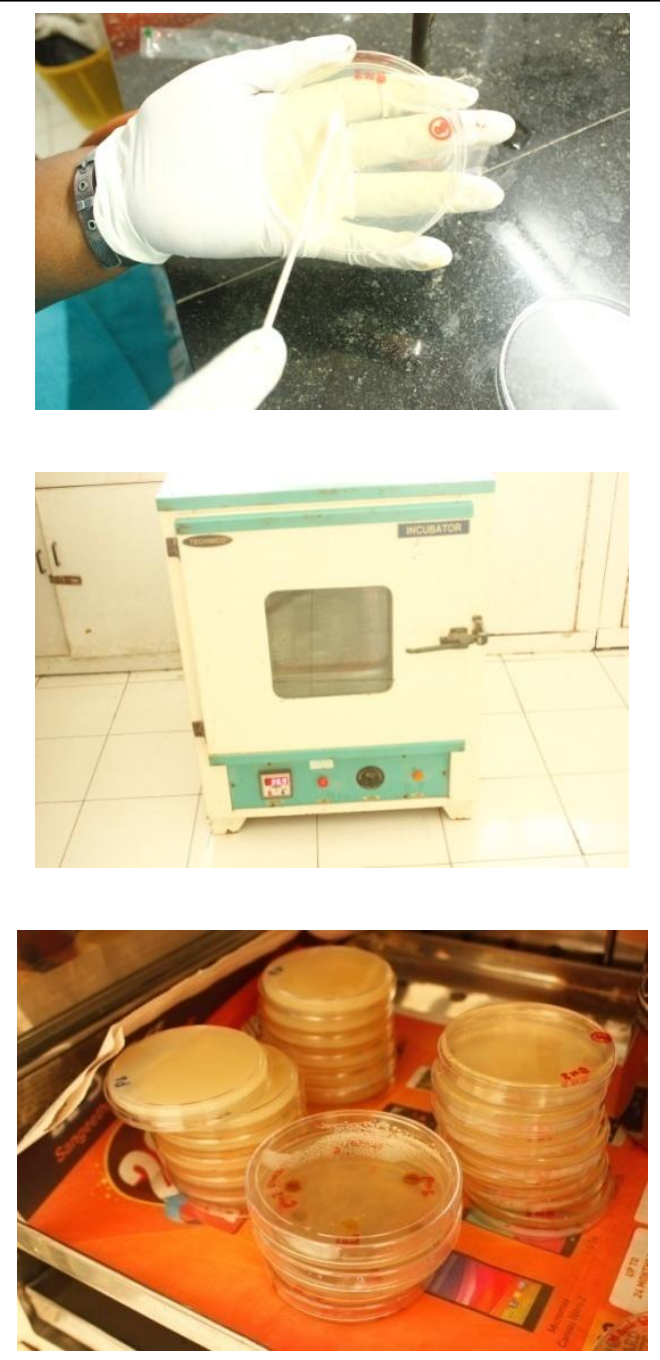

RESULT

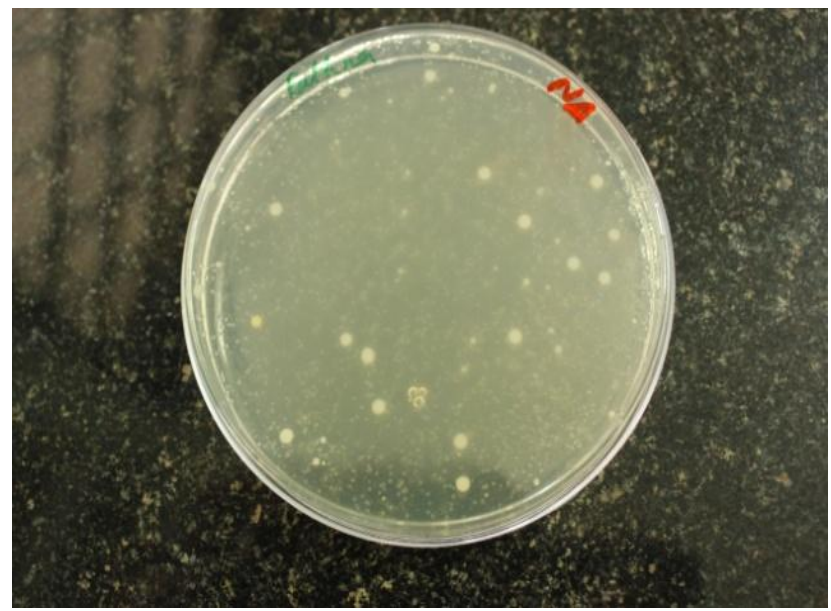

BACTERIAL COLONIES IN PLASTIC CUPS 


\section{BACTERIAL COLONIES IN STERLIZED STAINLESS STEEL CUPS}

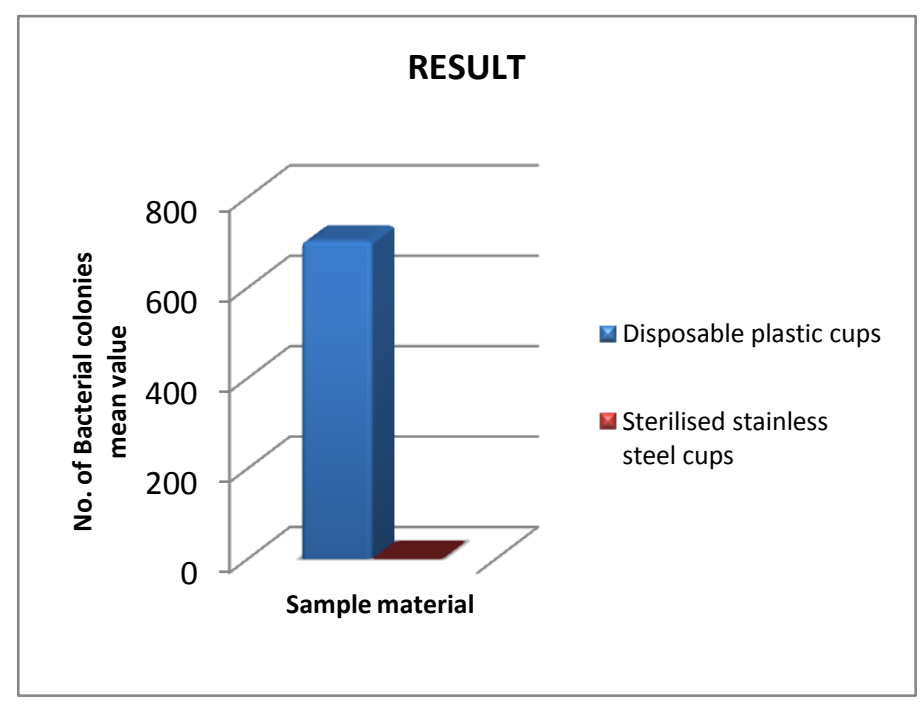

\section{DISCUSSION}

Plastic cups are made with oil, which is not a renewable source and cannot be reused, whereas stainless steel cups are reusable. Plastic cups, specially made with polystyrene and chemicals may leach into the beverage. This is more likely to happen with warm drinks (hot chocolate, tea and coffee) than with cold drinks. About $0.05 \mathrm{~g}$ chemical wastes is produced by per cup. Production of 1 tonne ( 0.98 long tons; 1.1 short tons) of plastic cup emits 135 pounds $(61 \mathrm{~kg})$ green house gases.

"One of the most ubiquitous and long-lasting recent changes to the surface of our planet is the accumulation and fragmentation of plastics," wrote David Barnes, a lead author and researcher for the British Antartic Survey. The report was published this month in a theme issue of Philosophical Transactions of The Royal
Society B, a scientific journal. Detectable levels of bisephenol A (BPA) from plastics have been found in urine of $95 \%$ of adults in the United States $^{[3]}$. While the U.S. Food and Drug Administration approves the use of Bisephenol A (BPA) for most food applications, in July 2012 the FDA amended its regulations to disallow the use of BPA in baby bottles and formula packaging. Chemicals added to plastics are absorbed by human bodies. Some of these compounds have been found to alter hormones or have other potential human health effects. Plastic debris, laced with chemicals and often ingested by marine animals, can injure or poison wildlife. Floating plastic wastes which can survive for thousands of years in water, serves as mini transportation devices for invasive species, disrupting habitats. Plastic buried deep in landfills can leach harmful chemicals that spread into groundwater. Around 4 percent of world oil production is used as a feedstock to make plastics, and a similar amount is consumed as energy in the process. When plastic is dumped in landfills, it interacts with water and form hazardous chemicals. When these chemicals seep underground, they degrade the water quality. Wind carries and deposits plastic from one place to another, increasing the land litter. It can also get stuck on poles, traffic lights, trees, fences, tower etc. and animals that may come in the vicinity and might suffocate them to death. Burning of plastic in the open air, leads to environmental pollution due to the release of poisonous chemicals. The polluted air when inhaled by humans and animals affect their health and can cause respiratory problems. Despite countless TV ads over the years showing ducks or dolphins trapped in six-ring plastic can holders, these items are still used and discarded every day $^{[4] .}$

As per our study, it has been proves that plastic cups used in clinical practices have lots of drawbacks. The two major reasons are, those plastic cups cannot be sterilized and contains too many microbes which may affect patients under dental treatment and also it cannot be recycled or 
decompose and so it enters the landfills and cause series of pollution. Therefore, it is always preferable to use stainless steel cups which can be autoclaved and kept sterile. These cups can be reused multiple times and is considered profitable when compared to disposable cups.

\section{REFERENCE}

1. Hanna Ziada, disposable coffee cups waste reduction study, December 15, 2009

2. Broca,Michale and Leon,Warren, The consumer's guide to effective environmental choices

1. Practical Advice from the Union of Concerned Scientist, 1999

2. 3.Claire Le Guern Lytle, when mermaids cry; the great plastic died, published in November 2009, plastic pollution.

3. Rachael stephens and Leighton Walter Kille, Plastics, human helath and environmental impacts: the road ahead, October 92014.

4. M Eriksen, LCM Lebreton, HS Carson, Martin Theil, Charles J. Moore, Jose C. Borerro, Francois Galgani, Peter G. Ryan, Julia Reisser: Plastic pollution in World's ocean: More than 5 Trillion Plastic pieces over weighing over 250,000 Tons Afloat at sea.

5. Rose E. Seavey, Sterile Processing Accreditation Surveys: Risk Reduction and Process Improvement, Published in issue: Oct. 2015, AORN journal, Vol. 102 